\title{
Current treatment of COVID-19 in renal patients: hope or hype?
}

\author{
Palumbo Roberto ${ }^{1}$. Londrino Francesco ${ }^{1}$ - Cordova Emanuela ${ }^{1} \cdot$ Gambardella Giorgia $^{1} \cdot$ Niscola Pasquale $^{2}$. \\ Dominijanni Sara ${ }^{1}$ (i)
}

Received: 13 May 2020 / Accepted: 12 September 2020 / Published online: 28 September 2020

(c) Società Italiana di Medicina Interna (SIMI) 2020

\begin{abstract}
To date the severe acute respiratory syndrome coronavirus 2 (SARS- CoV-2), known as COVID-19, is for clinicians the most difficult global therapeutic problem. In this landscape, the management of patients with chronic kidney disease, acute kidney injury or patients undergoing immunosuppressant therapies for kidney transplant or glomerular diseases, represent a clinical challenge for nephrologists, especially in patients with severe acute lung involvement. Therefore in this setting, due to the lack of anti-COVID treatment schedules, tailored management is mandatory to reduce the side effects, as consequence of impaired renal function and drugs interactions. We report the main treatment actually used against SARS-CoV-2, underlining its possible use in the nephropatic patients and the central role of nephrologists to improve the clinical outcome.
\end{abstract}

Keywords COVID-19 treatment $\cdot$ Chronic kidney disease $\cdot$ Nephrology $\cdot$ Antiviral therapy

\section{Introduction}

Despite the drastic containment measures implemented in many countries across the world, SARS-CoV-2 outbreak (also known as COVID-19), started in the city of Wuhan (Hubei province of China) in December 2019, is spreading all over the world [1, 2]. In this landscape, due to the sudden and rapid explosion of the infection and to the lack of new effective therapies, clinicians are investigating the effect of drugs used for other viral diseases. Recently, Alberici et al. reported the therapeutic management of the SARS$\mathrm{CoV}-2$ infection in a population of renal patients in the city of Brescia, in Italy (Brescia COVID Task Force) based on the disease activity $[3,4]$.

Currently, nephrologists are using the available drugs with particular attention to the renal impairment degree, interactions with other medications and, regarding dialysis patients, to the dialytic clearance. The novel SARSCoV-2 coronavirus is a RNA obligate intracellular virus and its replication depends on synthetic processes of the host cell. To date, none of the drugs currently used have

Dominijanni Sara

sara.dominijanni@gmail.com

1 Nephology and Dialysis Department, Sant'Eugenio Hospital, Rome, Italy

2 Ematology Department, Sant'Eugenio Hospital, Rome, Italy shown therapeutics effects. As a rule, to be effective, selective antiviral agents should block viral entry into the cell and should be active inside the host cell, whereas nonselective viral inhibitors may interfere with human cell function and promote the side effects.

The clinical onset of SARS-CoV-2 infection is variable from mild self-limited influenza-like symptoms to severe acute respiratory syndrome with possible association of multi-organ failure (MOF) secondary to cytokine storm and sometimes of haemophagocitic syndrome [3, 4]. It is noteworthy that in renal patients, the latter conditions represent a real challenge in terms of care and survival. The diagnosis of COVID-19 has to be confirmed by the reverse transcription polymerase chain reaction (RT-PCR) or gene sequencing for respiratory tract samples or by serologic test. Moreover, chest computed tomography (CT) represents an indispensable tool for screening and diagnosing COVID-19 patients. CT chest imaging in the early stages, from mild to severe cases, shows interstitial changes that developed into multiple ground glass opacification with or without consolidative abnormalities. Pleural effusions and mediastinal lymphnode enlargement should be detected in severe cases. Findings are often peripheral, bilateral and involving the lower lobes. Also chest X-ray can be considered a reliable diagnostic tool, especially in the emergency setting [2, 5-7]. Actually, the therapeutic management of SARS-CoV-2 infection has many fields of action. On one side to block the viral replication, on 
the other side to treat the interstitial pneumonia and MOF which cause the most severe clinical setting. Currently, the antiviral drugs available are: hydroxychloroquine (HCL), chloroquine (CL), azithromycin, lopinavir/ritonavir, darunavir/cobicistat, remdesivir, and favipavir. The other drugs, in particular those necessary to contrast the MOF and haemophagocytic syndrome are corticosteroids and monoclonal antibodies; also dialysis therapy with special filters should be used. Given the lack of specific therapy about the ongoing SARS-CoV-2 infection, we conducted a brief review to summarize the mechanism of action and the potentially side effects of the treatment currently available, focusing on the effects of the drugs on renal disease at different stages in terms of therapeutic management and survival.

\section{Drugs with antiviral activity}

\section{Hydroxychloroquine and chloroquine}

Hydroxychloroquine (HCL) and chloroquine (CL) are the cornerstone therapies of sensitive falciparum malaria and the second-line treatment of many rheumatologic diseases. Both drugs are currently under investigation for use in the SARS-CoV-2 outbreaks. CL and HCL were described as potent in vitro inhibitors for other coronaviruses, including SARS-CoV-1, so they are used in the treatment of SARSCoV-2 $[8,9]$. It has been demonstrated that SARS-CoV-2 links the angiotensin-converting enzyme 2 expressed in the lung. CL/HCL could also reduce the expression of sialic acids that may be required for binding SARS-CoV-2. Moreover, $\mathrm{CL} / \mathrm{HCL}$ increase endosomal $\mathrm{pH}$ required for virus/cell fusion, as well as interfering with the glycosylation of cellular receptors of SARS-CoV. Finally, CL/HCL interfere with the virion assembly through the blockage of cytokine storm reducing the pro-inflammatory mediators production and, consequently, the systemic inflammatory response syndrome (SIRS). In a Chinese study [9], patients diagnosed as mild, moderate, and severe cases of pneumonia received chloroquine $500 \mathrm{mg}$ twice per day for 10 days, improving clinical outcomes. Moreover, HCL plus azithromycin (AZT) are significantly associated with SARS-CoV-2 viral load reduction $[8,10-17]$ although the association leads to the more common side effect of QTc interval prolongation.

Recently, concerns have been raised about the toxicity of $\mathrm{CL}$ and HCL in patients with SARS-CoV-2 infection. In a multinational study, 96,032 COVID patients were enrolled. A group of 14,888 treated patients (1868 received chloroquine, 3783 received CL plus a macrolide, 3016 received HCL, and 6221 received HCL plus macrolide) was compared with 81,144 patients in the control group. A multivariate analysis showed that the treatments with $\mathrm{HCL}$ and $\mathrm{Cl}$ with or without a macrolide, were independently associated with an increased risk of in-hospital mortality.

Furthermore, the HCL regimens were independently associated with an increased risk of ventricular arrhythmia if compared with the control group [18].

In addition, Borba et al. have compared two dosage regimens of CL ( $450 \mathrm{mg}$ two times per day on day one then $450 \mathrm{mg}$ once daily for 5 days and $600 \mathrm{mg}$ two times per day for 10 days) and the study was finished early due to ventricular tachycardia and QTc prolongation especially in the high dose arm [19]. Based on the above studies, it is crucial to emphasize the importance of performing a tailor-made dosage of drugs through a continual monitoring of renal function which often worsens during SARS-CoV-2 infection, with risk of accumulation and significant increase in toxicity.

Ideal dose and duration of SARS-CoV-2 treatment are unknown. More data are available for HCL sulfate dose recommended in general population than CL: $200 \mathrm{mg}$, two times per day (BID) or three times per day (TID) for 10 days. The adjusted doses of HCL required for renal patients are based on the glomerular filtration rate (GFR). For GFR between 15 and $30 \mathrm{ml} / \mathrm{min}$ the suggested dose is $200 \mathrm{mg} / \mathrm{die}$ once a day (OD). For GFR $<15 \mathrm{ml} / \mathrm{min}$ the suggested dose is $200 \mathrm{mg}$ every other day (alternate days). CL is administered $500 \mathrm{mg}$ BID for 10 days. The adjusted doses of CL required for renal patients are: if GFR $<10 \mathrm{ml} / \mathrm{min}$, in hemodialysis (HD) and peritoneal dialysis (PD) $50 \%$ of dose should be administered. In continuous renal replacement therapy (CRRT), no dosage adjustment is required.

Standard dose, renal dose, and side effects of HCL, CL and of all the other drugs described below are summarized in Table 1. Side effects are reported in Table 2.

\section{Azithromycin}

AZT is a bacteriostatic antibiotic of macrolides class with a broad spectrum of activity against Gram-positive and atypical bacteria. The immune-modulatory and antiinflammatory effects of AZT take place by the downregulation of the inflammatory response, the reduction in cytokine production, and the induction of immunoglobulin antibodies production. Moreover, AZT is active in vitro against Zika and Ebola viruses [20, 21]. Given these properties, AZT and other macrolides have been studied for their potential use as target therapy for viral respiratory infections including MERS (Middle East respiratory syndrome) and SARS (severe acute respiratory syndrome). In a recent publication, the authors suggested that macrolide therapy had no significant association with MERS COV RNA clearance and was not associated with a significant change in 90-days patient mortality [22]. Furthermore, another study conducted in a small population suggested that the use of HCL in combination with AZT was 
Table 1 Standard dose and renal dose at different kidney disease stage

Dosage of drugs in adult patients with renal impairment (SARS-COV-2 disease)

\begin{tabular}{|c|c|c|c|c|c|c|c|}
\hline Drug & $\begin{array}{l}\text { Dose (normal } \\
\text { renal function) }\end{array}$ & $\mathrm{CrCl}>50-90$ & $\mathrm{CrCl} 10-50$ & $\mathrm{CrCL}<10$ & Hemodialysis & CAPD & CRRT \\
\hline \multicolumn{8}{|l|}{ Antimalarials } \\
\hline $\begin{array}{l}\text { Cloroquine } \\
\text { phosphate }\end{array}$ & $500 \mathrm{mg}$ po q12h & $500 \mathrm{mg} \mathrm{q} 12 \mathrm{~h}$ & $500 \mathrm{mg} \mathrm{q} 12 \mathrm{~h}$ & $\begin{array}{l}\text { Reducing dose } \\
50 \%\end{array}$ & $\begin{array}{l}\text { Reducing dose } \\
50 \%\end{array}$ & $\begin{array}{l}\text { Reducing dose } \\
50 \%\end{array}$ & $\begin{array}{l}\text { No adjustment } \\
\text { required }\end{array}$ \\
\hline $\begin{array}{l}\text { Hydroxy- } \\
\text { chloroquine } \\
\text { sulfate }\end{array}$ & $\begin{array}{l}200 \mathrm{mg} \text { po q8h } \\
\text { or } \mathrm{q} 12 \mathrm{~h}\end{array}$ & $\begin{array}{l}200 \mathrm{mg} \mathrm{q} 8 \mathrm{~h} \text { or } \\
\mathrm{q} 12 \mathrm{~h}\end{array}$ & $\begin{array}{l}\mathrm{CrCl} 15-30: \\
200 \text { mg q24h }\end{array}$ & $\begin{array}{l}\mathrm{CrCl}<15: \\
200 \mathrm{mg} \text { altera- } \\
\text { tive days }\end{array}$ & $\begin{array}{l}200 \text { mg altera- } \\
\text { tive days }\end{array}$ & $\begin{array}{l}\text { No data avail- } \\
\text { able }\end{array}$ & No data available \\
\hline \multicolumn{8}{|l|}{ Antibiotics } \\
\hline Azithromycin & $\begin{array}{l}250-500 \mathrm{mg} \mathrm{IV} / \\
\text { po q } 24 \mathrm{~h}\end{array}$ & $\begin{array}{l}250-500 \mathrm{mg} \\
\mathrm{q} 24 \mathrm{~h}\end{array}$ & $\begin{array}{l}250-500 \mathrm{mg} \\
\mathrm{q} 24 \mathrm{~h}\end{array}$ & $\begin{array}{l}250-500 \mathrm{mg} \\
\mathrm{q} 24 \mathrm{~h}\end{array}$ & $\begin{array}{l}250-500 \mathrm{mg} \\
\mathrm{q} 24 \mathrm{~h}\end{array}$ & $\begin{array}{l}250-500 \mathrm{mg} \\
\mathrm{q} 24 \mathrm{~h}\end{array}$ & $\begin{array}{l}250-500 \mathrm{mg} \\
\mathrm{q} 24 \mathrm{~h}\end{array}$ \\
\hline \multicolumn{8}{|l|}{ Antivirals } \\
\hline $\begin{array}{l}\text { Lopinavir/rito- } \\
\text { navir }\end{array}$ & $\begin{array}{l}\text { 400/100 mg po } \\
\text { q12h }\end{array}$ & $\begin{array}{l}400 / 100 \mathrm{mg} \\
\mathrm{q} 12 \mathrm{~h}\end{array}$ & $\begin{array}{l}400 / 100 \mathrm{mg} \\
\mathrm{q} 12 \mathrm{~h}\end{array}$ & $\begin{array}{l}400 / 100 \mathrm{mg} \\
\mathrm{q} 12 \mathrm{~h}\end{array}$ & $\begin{array}{l}400 / 100 \mathrm{mg} \\
\mathrm{q} 12 \mathrm{~h}\end{array}$ & $\begin{array}{l}\text { 400/100 mg } \\
\text { q12h }\end{array}$ & $\begin{array}{l}\text { No adjustment } \\
\text { required }\end{array}$ \\
\hline $\begin{array}{l}\text { Darunavir/ } \\
\text { cobicistat }\end{array}$ & $\begin{array}{l}1 \text { tab } \\
(800 / 150 \mathrm{mg}) \\
\text { po q24h }\end{array}$ & $\begin{array}{l}1 \text { tab } \\
(800 / 150 \mathrm{mg}) \\
\text { q24h }\end{array}$ & $\begin{array}{l}1 \mathrm{tab} \\
(800 / 150 \mathrm{mg}) \\
\text { q24h }\end{array}$ & $\begin{array}{l}1 \text { tab } \\
(800 / 150 \mathrm{mg}) \\
\text { q24h }\end{array}$ & $\begin{array}{l}1 \mathrm{tab} \\
(800 / 150 \mathrm{mg}) \\
\text { q24h }\end{array}$ & $\begin{array}{l}1 \mathrm{tab} \\
(800 / 150 \mathrm{mg}) \\
\text { q24h }\end{array}$ & $\begin{array}{l}\text { No adjustment } \\
\text { required }\end{array}$ \\
\hline Favipavir & $\begin{array}{l}1600 \mathrm{mg} \text { po } \\
\text { q12h on Day } \\
1 \text { followed by } \\
600 \mathrm{mg} \mathrm{q} 12 \mathrm{~h}\end{array}$ & $\begin{array}{l}\text { No data avail- } \\
\text { able }\end{array}$ & $\begin{array}{l}\text { No data avail- } \\
\text { able }\end{array}$ & $\begin{array}{l}\text { No data avail- } \\
\text { able }\end{array}$ & $\begin{array}{l}\text { No data avail- } \\
\text { able }\end{array}$ & $\begin{array}{l}\text { No data avail- } \\
\text { able }\end{array}$ & No data available \\
\hline Remdesivir & $\begin{array}{l}200 \mathrm{mg} \text { po } \\
\text { q24h on Day } \\
1 \text { followed by } \\
100 \mathrm{mg} \mathrm{q} 24 \mathrm{~h}\end{array}$ & $\begin{array}{l}200 \mathrm{mg} \text { poq } 24 \mathrm{~h} \\
\text { on day } 1 \\
\text { followed by } \\
100 \mathrm{mg} \mathrm{q} 24 \mathrm{~h}\end{array}$ & $\begin{array}{l}\text { CrCl 50-30: } \\
200 \text { mg po } \\
\text { q24h on Day } \\
1 \text { followed by } \\
100 \text { mg q24h }\end{array}$ & $\begin{array}{c}\mathrm{CrCl}<30: \\
\text { Avoid use }\end{array}$ & Avoid use & Avoid use & Avoid use \\
\hline \multicolumn{8}{|c|}{ Monoclonal antibody } \\
\hline Tocilizumab & $8 \mathrm{mg} / \mathrm{Kg} \mathrm{q} 12 \mathrm{~h}$ & $\begin{array}{l}\text { No adjustment } \\
\text { required }\end{array}$ & $\begin{array}{l}\text { No adjustment } \\
\text { required }\end{array}$ & $\begin{array}{l}\text { No adjustment } \\
\text { required }\end{array}$ & $\begin{array}{l}\text { No data avail- } \\
\text { able }\end{array}$ & $\begin{array}{l}\text { No data avail- } \\
\text { able }\end{array}$ & No data available \\
\hline Eculizumab & $\begin{array}{l}900 \text { mg IV } \\
\text { every } 7 \text { days }\end{array}$ & $\begin{array}{l}\text { No adjustment } \\
\text { required }\end{array}$ & $\begin{array}{l}\text { No adjustment } \\
\text { required }\end{array}$ & $\begin{array}{l}\text { No adjustment } \\
\text { required }\end{array}$ & $\begin{array}{l}\text { No data avail- } \\
\text { able }\end{array}$ & $\begin{array}{l}\text { No data avail- } \\
\text { able }\end{array}$ & No data available \\
\hline Sarilumab & $\begin{array}{l}\text { No data avail- } \\
\text { able }\end{array}$ & $\begin{array}{l}\text { No adjustment } \\
\text { required }\end{array}$ & $\begin{array}{l}\text { No adjustment } \\
\text { required }\end{array}$ & $\begin{array}{l}\text { No adjustment } \\
\text { required }\end{array}$ & $\begin{array}{l}\text { No adjustment } \\
\text { required }\end{array}$ & $\begin{array}{l}\text { No adjustment } \\
\text { required }\end{array}$ & $\begin{array}{l}\text { No adjustment } \\
\text { required }\end{array}$ \\
\hline Anakinra & $\begin{array}{l}100 \mathrm{mg} \text { by IV } \\
\text { infusion every } \\
6 \mathrm{~h} \text { (total of } \\
400 \mathrm{mg} \text { daily) } \\
\text { for } 15 \text { days }\end{array}$ & $\begin{array}{l}\text { No adjustment } \\
\text { required }\end{array}$ & $\begin{array}{l}\text { No adjustment } \\
\text { required }\end{array}$ & $\begin{array}{l}\text { No adjustment } \\
\text { required }\end{array}$ & $\begin{array}{l}\text { No adjustment } \\
\text { required }\end{array}$ & $\begin{array}{l}\text { No adjustment } \\
\text { required }\end{array}$ & $\begin{array}{l}\text { No adjustment } \\
\text { required }\end{array}$ \\
\hline \multicolumn{8}{|l|}{ Corticosteroids } \\
\hline Desametasone & $\begin{array}{l}1-2 \mathrm{mg} / \mathrm{Kg} \text { IV/ } \\
\text { po q24h }\end{array}$ & $\begin{array}{l}1-2 \mathrm{mg} / \mathrm{Kg} \\
\mathrm{q} 24 \mathrm{~h}\end{array}$ & $\begin{array}{l}1-2 \mathrm{mg} / \mathrm{Kg} \\
\mathrm{q} 24 \mathrm{~h}\end{array}$ & $\begin{array}{l}1-2 \mathrm{mg} / \mathrm{Kg} \\
\mathrm{q} 24 \mathrm{~h}\end{array}$ & $\begin{array}{l}20 \mathrm{mg} \mathrm{q} 24 \mathrm{~h} \\
\text { for } 5 \text { days } \\
\text { followed by } \\
10 \mathrm{mg} \mathrm{q} 24 \mathrm{~h} \\
\text { for } 5 \text { days }\end{array}$ & $\begin{array}{l}\text { No data avail- } \\
\text { able }\end{array}$ & No data available \\
\hline $\begin{array}{l}\text { Methylpredni- } \\
\text { solone }\end{array}$ & $\begin{array}{l}\text { 40-80 mg IV } \\
\text { q24h }\end{array}$ & $\begin{array}{l}40-80 \mathrm{mg} \text { IV } \\
\text { q24h }\end{array}$ & $\begin{array}{l}\text { 40-80 mg IV } \\
\text { q24h }\end{array}$ & $\begin{array}{l}40-80 \mathrm{mg} \text { IV } \\
\text { q24h }\end{array}$ & $\begin{array}{l}\text { No data avail- } \\
\text { able }\end{array}$ & $\begin{array}{l}\text { No data avail- } \\
\text { able }\end{array}$ & No data available \\
\hline
\end{tabular}

$\mathrm{CrCl}$ creatinine clearance, $C A P D$ continuous ambulatory peritoneal dialysis, $C R R T$ continuous renal replacement therapy, $I V$ intravenous, $P o$ oral dosage

associated with significant viral load reduction in SARSCoV-2 infected patients, although the risk of QT prolongation induced by the association of the two drugs should be considered. As for each treatment, the cost benefits of the risk should be individually evaluated [10]. In April
2020, two clinical trials began to verify the efficacy of AZT therapy in SARS-CoV-2. Currently there is no clear evidence of the efficacy of AZT treatment in SARS-CoV-2 pneumonia [23, 24]. The WHO guidelines and Surviving Sepsis Campaign Guidelines (March 2020) recommended 
Table 2 Side effects

\begin{tabular}{|c|c|}
\hline Drug & Side effect \\
\hline Hydroxychloroquine & $\begin{array}{l}\text { Pruritus, anorexia, nausea, abdominal pain, blurring of vision, hypotension, QT prolongation -expectially in association } \\
\text { with azithromycin, -hemolysis in G6PD-deficient, granulocytosis, anaphylactoid reaction, anaphylaxis, angioedema, } \\
\text { alopecia, exfoliative dermatitis, ototoxicity, confusion, psychosis, seizures }\end{array}$ \\
\hline Chloroquine & Retinopathy, anorexia, nausea, vomiting, headache, dizziness, blurred vision, QT prolongation \\
\hline Azytromicin & diarrhea, nausea, vomiting, severe QT prolongation, abdominal pain \\
\hline Lopinavir/Ritonavir & $\begin{array}{l}\text { Prostration, anorexia, abdominal pain, diarrhea, nausea and vomiting, paresthesia, high level of AST, ALT, CK, pan- } \\
\text { creatitis, QT prolongation, headache, dyslipidemia, and taste alterations }\end{array}$ \\
\hline Darunavir/cobicistat & $\begin{array}{l}\text { Abdominal pain, prostration, anorexia, diarrhea, nausea and vomiting, rash, urticaria, Steven-Johnson syndrome, Drug } \\
\text { Reaction with Eosynophilia and Systemic Symptoms, increased risk of bleeding in haemofiliac patients, reduction in } \\
\text { eGFR (cobicistat), headhache, increase in liver enzymes, increase in fats levels, immune reconstitution syndrome }\end{array}$ \\
\hline Remdesivir & Diarrhea, increase liver enzymes blood levels \\
\hline Favipavir & Theratogenicity \\
\hline Corticosteroids & $\begin{array}{l}\text { Osteoporosis, osteonecrosis, hypertension, diabetes, fluid retention, cataracts and glaucoma, gastritits and gastric ulcera, } \\
\text { increase risk of superinfection, neuropsychiatric adverse effects }\end{array}$ \\
\hline Monoclonal antibodies & $\begin{array}{l}\text { Tociluzumab: increased serious infections, reactivation of latent tuberculosis, headache, hypertension, hepatitis } \\
\text { Eculizumab: hypertension, tachycardia, peripheral edema, hypotension, headache insomnia, fatigue, dizziness, skin } \\
\text { rash, pruritus, hypokalemia, diarrhea, vomiting, nausea, abdominal pain, gastroenteritis, infection, life-threatening } \\
\text { neisseria meningitides } \\
\text { Sarilumab increased serum alanine aminotransferase, increased serum aspartate aminotransferase. Infection. Decreased } \\
\text { platelet count, leukopenia, neutropenia } \\
\text { Anakinra injection-site reaction, headache, vomiting, arthralgia, nasopharyngitis, nausea, fever, nausea, diarrhea, } \\
\text { eosinophilia, decreased white blood cell count, change in platelet count }\end{array}$ \\
\hline
\end{tabular}

empiric antimicrobial therapy only for prevention or treatment of superinfections [25].

The dose recommended for patients with mild to severe symptoms is $500 \mathrm{mg}$ OD for three days. In patient with severe CKD (GFR $<10 \mathrm{ml} / \mathrm{min})$, dose adjustment is required (50\% of dose).

\section{Antiviral drugs}

\section{Lopinavir/ritonavir}

The co-formulation lopinavir/ritonavir is one of the main treatment for HIV infections. Lopinavir is a HIV protease inhibitor, whereas ritonavir inhibits the CYP3A-mediated metabolism of lopinavir providing to increase plasma level of lopinavir. Furthermore, lopinavir is mainly metabolized and eliminated by the liver [26]. Many studies, carried out during the past epidemic respiratory syndromes (SARS and MERS), suggested a reduction in viral load, steroid usage and, consequently, in nosocomial infections, in patients treated with lopinavir/ritonavir, showing a clinical improvement [27, 28]. A randomized clinical trial, handled by a Chinese group, suggested that in hospitalized adult patients with severe infection, no benefit was observed with lopinavir/ritonavir beyond standard care in terms of time to clinical improvement, reduction of mortality and safety (side effects and discontinuation of treatment) [29, 30]. The recommended doses of lopinavir/ritonavir are 400/100 mg BID for 5-10 days [31-33]. This therapeutic schemes has been suggested in symptomatic elderly patients with underlying diseases or patient with acute respiratory distress syndrome (ARDS) when Remdesivir is not available (mild/high-risk groups) starting from the early stage. Lopinavir pharmacokinetics have not been studied in patients with renal disease; however, since the renal clearance of drug is negligible, a decrease in total body clearance is not expected in patients with renal disease. In HD, PD and CRRT, no dosage adjustment is required.

\section{Darunavir/cobicistat}

Darunavir (DRV) is a HIV protease inhibitor that blocks the cut of Gag-Pol proteins encoded by HIV in the cells infected by the virus preventing the development of mature infective viral particles. It was initially used in combination with ritonavir [34] and then boosted with cobicistat [35]. Cobicistat is a booster for the improvement of pharmacokinetics and pharmacodynamics of DRV by cytochrome P450 (CYP3A) inhibition [36]. Darunavir/cobicistat (DRV/c) is approved by the United States Food and Drug Administration (FDA) only for use with a boosting agent, and in combination with other anti-retrovirals, for the treatment of HIV-1 infection. Janssen Pharmaceutical Companies, a subsidiary of Johnson\&Johnson, yielded its brand DRV/c used for HIV treatment for the use in activities research for SARSCoV-2 treatment. Anecdotal reports suggested that darunavir has potential antiviral activity against SARS-CoV-2 virus. 
Janssen have found low interactions between DRV and the active site of SARS- CoV-2 protease. Actually, the use of DRV as treatment for SARS-CoV-2 is not supported by in vitro or clinical studies [37,38]. DRV/c is metabolized by the liver. Caution, without any dose adaptation, is suggested in case of slight and mild liver dysfunction, whereas the use of DRV/c is not recommended in case of severe liver dysfunction. Actually, the therapeutic scheme for the treatment of SARS-CoV-2 infection is off-label. The drug doses suggested is $800 / 150 \mathrm{mg}$ OD for $5-7$ days. DRV/c has the same mechanism of action of lopinavir/ritonavir; therefore, it is reasonable to consider the use of DRV/c as an alternative treatment for SARS-CoV-2 infection disease when lopinavir/ritonavir is not available [39]. DRV is poorly eliminated by the kidney [40]; changing in dosage is not requested in patient with renal disease. Instead, considering that cobicistat should reduce the renal clearance, its use is contraindicated in patient with GFR $<70 \mathrm{ml} / \mathrm{min}$. Finally, no evidence or clinical study is available regarding the dialysis clearance [35].

\section{Remdesivir}

Remdesivir (RDV) is a novel antiviral drug, recently used for the Ebola treatment. RDV is an adenosine nucleotide analogue with a broad spectrum of antiviral activity. It works as RNAdependent RNA polymerase (RpRd) inhibitor. RDV creates a tightly bind with RpRd, showing a high level of binding affinity comparable to these of native nucleotides. RDV inhibits viral replication through premature termination of RNA, blocking the transcription and consequently the viral replication [41]. RDV has been studied in clinical trials and it is still under investigation for the Ebola treatment in humans, MERS, and SARS-CoV viruses [42, 43]. It is currently under investigation for SARS-CoV-2 treatment. Indeed, clinical trials are currently in progress to verify the efficacy and safety of RDV use in hospitalized adult patients with mild or severe SARS-CoV-2 disease [44, 45]. Successful results have been reached in one case of SARS-CoV-2-infected patients treated with intravenous RDV [46]. RDV is a prodrug, predominantly metabolized by hepatic enzymes with hydrolase activity. Based on rapid distribution, metabolism and clearance, the drug has scarce clinically significant interactions and does not prolong the QTc interval [47]. There are three different therapeutic schemes proposed by the ongoing trials; all of them share the same dosage but differ in the duration of the treatment based on the clinical stage of the disease (mild or severe). The recommended dose of RDV is $200 \mathrm{mg}$ intravenous (IV) on day 1 , $100 \mathrm{mg}$ IV daily for 5 up to 10 days. The use of RDV has not been approved by FDA (Food and Drug Administration) and EMA (European Medicines Agency) even if its compassionate use is recommended in patients with severe SARS-CoV-2 infection who are not eligible for inclusion criteria in clinical trials and in absence of alternative therapeutic options [48].

In a recent randomized, double-blinded, placebo-controlled, multicenter trial, the efficacy of the RDV in adults hospitalized SARS-CoV-2 patients with pulmonary involvement has been demonstrated. RDV has received the authorization for the treatment of suspected or laboratory-confirmed SARS-CoV-2 adults and children hospitalized patients with severe disease (low blood oxygen levels, needing oxygen therapy, needing mechanical ventilation), due to shortening the time to recovery [49]. The proposed dosage is: $200 \mathrm{mg}$ as a single dose on day 1 , followed by $100 \mathrm{mg}$ once daily. Instead, the renal recommended doses are: if eGFR $\geq 30 \mathrm{ml} / \mathrm{min}$ no dosage adjustment necessary, if eGFR $\leq 30 \mathrm{ml} / \mathrm{min}$ avoid use, in renal replacement therapies avoid use.

\section{Favipavir}

The antiviral 6-fluoro-3-hydroxy-2-pyrazinecarboxamide (T-705, favipiravir) Favipavir (FP) is a RNA-dependent RNA polymerase (RdRp) inhibitor. Its use was approved only in Japan for the treatment of influenza infection and it is distributed only upon request by the Minister of Health, Labor and Welfare of Japan to avoid irrational prescriptions [50] In addition to its anti-influenza activity, FP blocks the replication of other RNA viruses [51]. FP has been used for the treatment of human infection with life-threatening Ebola virus and severe fever with thrombocytopenia syndrome [52]. Moreover, the FP activity against multiple RNA viruses has been demonstrated [53]. Due to its inhibition of RNA polymerase, FP may have potential antiviral activity on SARS-CoV-2 infection [54]. The preliminary results of a clinical Chinese trial suggested that FP should have stronger antiviral action than lopinavir/ritonavir [55]. FP was approved in China for SARS-CoV-2 treatment since February 15, 2020 [56]. Dosage and treatment duration for SARS-CoV-2 infection are unavailable. The approved FP dose in Japan is $1600 \mathrm{mg}$ TID on day 1 followed by $600 \mathrm{mg}$ TID for 4 days. The viral replication period is 6 days or longer for seasonal influenza. When drug administration is stopped during the virus replication period or when resistant strains appear, virus replication and fever relapse. Thus, 10 days of administration should be required for severe influenza or novel influenza [57]. However, no published clinical studies are available about the efficacy and safety of the drug in the treatment of SARS-CoV-2 disease.

\section{Other therapies}

\section{Corticosteroids}

Corticosteroids (CST) are immunomodulatory agents that modulate the host response by the secretion of various 
interleukins (IL-1, IL-6, IL-8, IL-11, IL-12, IFN- $\gamma$ e TNF$\alpha)$ and the expression of their receptors. Some corticosteroids attenuate the $\mathrm{CD} 28$ co-stimulatory pathway through the inhibition of naïve T-cell proliferation and differentiation, a key mechanism in the pathogenesis of ARDS in SARS-CoV2-associated pneumoniae. CTS have been largely used in the treatment of past coronavirus infection (SARS, MERS). No evidence was found on the antiviral effect of corticosteroids alone in resisting SARS-CoV-2 in vivo and in vitro [58-60]. The dose of methylprednisolone varied, depending on disease severity. Moreover, administration of CST in the early phases of SARS-CoV-2 infection, is not recommended due to the increasing risk of superinfection and prolonged viral replication [61]. However, it has been demonstrated that methylprednisolone may be beneficial for patients with SARS-CoV-2 pneumonia who have developed ARDS on progression [62]. The use of systemic CST in adults with SARS-CoV-2 and ARDS mechanically ventilated has been suggested by Guidelines on the Management of Critically Ill Adults with Coronavirus Disease 2019 (COVID-19) of Surviving Sepsis Campaign (weak recommendation, low-quality evidence). Systemic CST are recommended for a short-term use $(1 \sim 2 \mathrm{mg} \cdot \mathrm{kg} \times 3 \sim 5$ days $)$ [25, 63]. In patients on chronic dialysis or with renal transplant and rapid progression of SARS-CoV-2 disease the guidelines of the "Brescia Renal Covid Task force" indicate an initial dose of desametasone $20 \mathrm{mg} / \mathrm{die}$ for 5 days followed by a dose of $10 \mathrm{mg}$ die for 5 days [3, 4].

\section{Monoclonal antibody}

Tociluzumab. Tociluzumab (TC) is a humanized monoclonal antibody $(\mathrm{mAb})$ anti-human IL-6 receptor of the IgG1 subclass. TC, interrupting IL-6 pathway, seems to be highly effective in reducing the inflammatory response through its pro-inflammatory effects and it has been successfully used for the treatment of rheumatologic diseases. The use of TC for the treatment of SARS-CoV-2 infection has shown encouraging preliminary clinical results. Nevertheless, the right time of therapy initiation, the duration and the recommended dose are not fully clear. A multicenter, randomized controlled trial is ongoing in the investigation of the efficacy and safety of TC in the treatment of new coronavirus pneumonia [64-67]. Moreover, a screening for tuberculosis and hepatitis B infection should be done before initiating TC. The Brescia Renal COVID Task Force [3, 4] suggested a dose of $8 \mathrm{mg} / \mathrm{Kg} \mathrm{IV}$, repeatable after $12 \mathrm{~h}$.

Eculizumab A multicenter trial (NCT04288713) is underway on Eculizumab (EZ), a humanized $\mathrm{mAb}$ that binds the complement component $\mathrm{C} 5$, which is required for formation of the membrane attack complex (MAC); MAC can cause organs' damage in other types of coronaviruses infection; therefore, modulation of this part of the immune response during SARS-CoV-2 infection can be helpful. In unvaccinated patients against Neisseria meningitides daily antimicrobial prophylaxis is mandatory (ceftriaxone iv) to avoid life-threatening infections. EZ dose recommended is $900 \mathrm{mg}$ IV every 7 days [65].

Sarilumab Sarilumab (SA) is a specific $\mathrm{mAb}$ for the interleukin-6 (IL-6) receptor; it may potentially contrast cytokine release syndrome in severely ill patients of COVID-19 disease $[68,69]$.

Anakinra. Anakinra (AnK). AnK is a recombinant human interleukin-1 (IL-1) receptor antagonist. NCT04324021 is a phase 3 randomized, open-label, multicenter trial on AnK. Dose is $100 \mathrm{mg}$ every $6 \mathrm{~h}$ (total of $400 \mathrm{mg}$ daily) for 15 days [70].

Since the elimination through the kidney of $\mathrm{mAb}$ is considered not significant, in CKD patients no dosage adjustment is required.

\section{Convalescent plasma}

Treatment of acute severe pneumonia with immunoglobulin from healed patients could accelerate clinical recovery. Currently several trials are ongoing in China [71, 72].

\section{Renal replacement therapies}

In some patients with SARS-CoV-2 infection, the systemic involvement should induce acute kidney injury (AKI) and MOF. The cause of MOF in patients with SARS-CoV-2 pneumonia, similar to septic shock, is an uncontrolled inflammatory state or a subsequent immune-paralysis. When pharmacological treatment is not effective, extracorporeal therapies offer a possibility to support different organs in a multiple organ dysfunction [73]. The indications for extracorporeal therapy in patients with SARS-CoV-2 infection and MOF include renal replacement therapy and sepsis. AKI, in patients affected by SARS-CoV-2-related pneumonia, is uncommon, but it might result from a SIRS involving combined myocardial and kidney function. In sepsis, Ronco et al. observed the reduction of circulating levels of cytokines using cartridges containing highly biocompatible sorbents and microporous resins (ex. Cytosorb). The suggested schemes of application is 1 unit every $12 \mathrm{~h}$ in the first $24 \mathrm{~h}$ and 1 unit per day in the following 2 days [74]. In dialysis patients with chronic kidney disease (CKD), Alberici et al. suggested expanded intermittent hemodialysis (HDx) whit medium cut-off (MCO) membrane to increase removal of inflammatory cytokines [3, 4].

\section{Low molecular weight heparin}

High rate of pulmonary thromboembolism due to thrombophilic and inflammatory state has been reported. Therefore, 
the prophylactic use of low molecular weight heparin (LMWH) is indicated $[75,76]$.

\section{Discussion}

Since the SARS-CoV-2 outbreak began, last December 2019 in China, millions of people have been infected; SARS$\mathrm{CoV}-2$ should cause a large spectrum of clinical signs and symptoms ranging from mild to critical [1,2]. Currently, there are no vaccines or drugs approved for prevention and treatment of the infection. Moreover, the kidney involvement of the SARS-CoV-2 infection should be associated with three different clinical settings. The first includes patients with CKD, the second includes patients with AKI, the third includes immunosuppressed patients such as renal graft recipients or patients with glomerular diseases. Moreover, it is known that kidney injury is associated with an increased risk of death in patients with influenza A virus subtype H1N1 and SARS [77, 78]. In addition, a recent report suggested that the kidney involvement, in patients infected by SARS-CoV-2 at admission, is associated with a higher risk of in-hospital death [79]. AKI SARS-CoV-2 related is probably multifactorial, including a major role of inflammatory cytokines. In severe cases, cytokine storm causes a multiple organ failure syndrome, including kidney's disease [80]. Kidney histology was examined in an autopsy series of 26 patients with evidence of acute tubular damage. Nine biopsies were tested for intracellular virus and coronaviruses were identified in seven [81]. To date, two cases were reported with collapsing glomerulopathy presenting with severe AKI and heavy proteinuria [82, 83].

Since the clinical presentation of SARS-CoV-2 infection should be misleading until the severe stages, with rapid clinical deterioration, clinicians should pay more attention to renal patients, carrying out early treatment and intensive monitoring to improve the clinical outcome. Alberici et al. $[3,4]$ describe the experience of the Nephrology Ward of the University Hospital of Brescia in the northern of Italy, place of a dramatic COVID-19 outbreak, focusing the attention on dialysis and transplant patients. The authors suggested a better outcome especially in the setting of the transplanted group managed by a dedicated Nephrology Unit. Preliminary results on general population with mild symptoms suggested a synergic effect of HCL in combination with AZT, with a possible preventive effect of severe respiratory tract infections, in order to confirm the antiviral activity showed against SARS-CoV-1, Zika and Ebola viruses [45-48]. On the basis of the latest toxicity warnings, when using CL and HCT, it is crucial to adapt the dosage to the renal function to avoid the overload and to carry out a close monitoring of the side effects, particularly cardiological ones. During this phase, nephrologist should consider the possibility to combine antiviral therapy and standard drugs, although in a recent trial, no benefit was observed with the association of lopinavir/ritonavir treatment [29]. In severe cases of MOF and haemophagocitic syndrome, immunosuppressive strategies must be considered. The massive lung involvement and interstitial infiltrates with respiratory failure $(\mathrm{PaO} 2 /$ $\mathrm{FiO}<100)$ is usually considered the main life-threatening process of SARS-CoV-2 infection. Moreover, the administration of high dose of steroids in association with monoclonal antibody as rescue procedures was strongly suggested $[3,4]$.

Unfortunately, to date, a monoclonal antibody against SARS-CoV-2 has not been developed and TC is the most used in ongoing studies. When SARS-CoV-2 infection causes AKI unresponsive to pharmacological treatment, renal replacement therapy is necessary. Moreover, in severely ill patients with sepsis/MOF or haemophagocitic syndrome, extracorporeal therapies with highly biocompatible resins are also used and seem to have a remarkable benefit in terms of hemodynamic support and organ function rescue $[73,74]$. Convalescent plasma could be a promising approach in selected cases with severe disease [71, 72].

In renal transplant recipients and glomerulonephritis patients affected by SARS-CoV-2 infection, it is mandatory to verify the interactions of the drugs with immunosuppressive therapies to reduce and/or avoid harmful side effects. Notably, it has been suggested to discontinue calcineurin inhibitors and antimetabolite in renal graft recipients, using only low doses of CST as anti-rejection therapies [3, 4]. Pulmonary thromboembolism prophylaxis is useful in all patients with COVID-19 infection $[75,76]$.

In COVID-19 pediatric kidney patient, RDV is preferred to other agents. It is described a multisystem inflammatory syndrome (MIC-S) that shares clinical features with Kawasaki disease. Children who present with clinical features of MIS-C should be treated with steroid and if refractory, with monoclonal antibody (Anakinra, tocilizumab) [84].

Finally, we would underline the nephrologists' role and its importance in the global clinical evaluation in kidney patients suffering from COVID-19 disease. Waiting for the availability of new drugs, nephrologists should contribute to choose the best therapy for renal patients in order to reserve the kidney function, to consider possible interactions between drugs and to avoid nephrotoxicity of combined therapies. Furthermore, in unclear cases of renal function impairment, a kidney biopsy would be mandatory.

\section{Conclusion}

In conclusion, the SARS-CoV-2 outbreaks therapy represents for clinicians one of the most difficult challenge. Within this setting, renal patients represent a population at 
high risk of morbidity and mortality, requiring a tailored therapeutic approach. Moreover, it is well known that the therapeutic target to treat patients with $\mathrm{CKD}, \mathrm{AKI}$, and kidney transplant is complicated by pharmacodynamics and pharmacokinetics aspects, drug interactions, and extracorporeal therapies. Thus, there are no doubts that in renal patients, within the SARS-CoV-2 infection management, the role of nephrologists is useful in order to draw a balance between beneficial and potentially harmful effects of current treatment available.

Author contributions PR, LF, and DS conceived of the study and participated in its organization and coordination. LF, GG, CE, and NP contributed to the acquisition of scientific materials. LF, GG, CE, and DS drafted the manuscript. All authors contributed to the interpretation of data, manuscript revisions, and read and approved the final manuscript.

\section{Compliance with ethical standards}

Conflict of interest The author(s) declare that they have no conflict of interest.

Ethical approval Not required for this paper.

Informed consent For this type of study, formal consent is not required.

\section{References}

1. Wu Z, Mc Googan JM (2020) Characteristics of and important lessons from the coronavirus disease 2019 (COVID-19) outbreak in China: summary of a report of 72314 cases from the Chinese center for disease control and prevention. JAMA. https://doi. org/10.1001/jama.2020.2648(Epub ahead of print)

2. Huang C, Wang Y (2020) Li X et al Clinical features of patients infected with 2019 novel coronavirus in Wuhan. China Lancet 395(10223):497-506. https://doi.org/10.1016/S0140 -6736(20)30183-5(Epub 2020 Jan 24)

3. Alberici F, Delbarba E, Manenti C et al (2020) Management of patients on dialysis and with kidney transplant during SARSCOV2 (COVID-19) pandemic in Brescia Italy. Kidney Int Rep. https:// doi.org/10.1016/j.ekir.2020.04.001

4. Alberici F, Del Barba E, Manenti C et al (2020) Gestione del paziente in dialisi e con trapianto di rene in corso di infezione da coronavirus Covid 19. Giornale Italiano di nefrologia Anno 37:2

5. Ying-Hui J, Lin C, Zhen-Shun C et al (2020) A rapid advice guideline for the diagnosis and treatment of 2019 novel coronavirus (2019-nCoV) infected pneumonia (standard version). Mil Med Res 7:4

6. Pan Z, Yanbing D, Xia W et al (2020) The epidemiology, diagnosis and treatment of COVID-19. Antimicrob Agents 55(5):105955

7. Ippolito D, Maino C, Pecorelli A et al (2020) Chest X-ray features of SARS-CoV-2 in the emergency department: a multicenter experience from northern Italian hospitals. Respir Med 170:106036. https://doi.org/10.1016/j.rmed.2020.106036(Online ahead of print)

8. Devaux CA, Rolain JM, Colson P, Raoult D (2020) New insights on the antiviral effects of chloroquine against coronavirus: what to expect for COVID-19? Int J Antimicrob Agents. https://doi. org/10.1016/j.ijantimicag.2020.105938(Online ahead of print)
9. Zhonghua Jie He He Hu Xi Za Zhi, (2020) Expert consensus on chloroquine phosphate for the treatment of novel coronavirus pneumonia, Multicenter collaboration group of Department of Science and Technology of Guangdong Province and Health Commission of Guangdong Province for chloroquine in the treatment of novel coronavirus pneumonia. 43(3):185-188. https://doi. org/10.3760/cma.j.issn.1001-0939.2020.03.009. Chinese

10. Gautret P, Lagier JC, Parola P et al (2020) Hydroxychloroquine and azithromycin as a treatment of COVID-19: results of an openlabel non-randomized clinical trial. Int J Antimi-Crob Agents. https://doi.org/10.1016/jantimicag.2020.105949(In Press)

11. Cortegiani A, Ingoglia G, Ippolito M et al (2020) A systematic review on the efficacy and safety of chloroquine for the treatment of COVID-19. J Crit Care. https://doi.org/10.1016/j. jcrc.2020.03.005

12. Colson P, Rolain JM, Lagier JC et al (2020) Chloroquine and hydroxychloroquine as available weapons to fight COVID-19. Int J Antimicrob Agents. https://doi.org/10.1016/j.ijantimica g.2020.105932

13. Gao J, Tian Z, Yang X (2020) Breakthrough: chloroquine phosphate has shown apparent efficacy in treatment of COVID-19 associated pneumonia in clinical studies. Biosci Trends 14:72-73. https://doi.org/10.5582/bst.2020.01047

14. Yao X, Ye F, Zhang M et al (2020) In vitro antiviral activity and projection of optimized dosing design of hydroxychloroquine for the treatment of severe acute respiratory syndrome coronavirus 2 (SARS-CoV-2). Clin Infect Dis. https://doi.org/10.1093/cid/ciaa2 37(In Press)

15. Vincent MJ, Bergeron E, Benjannet $S$ et al (2005) Chloroquine is a potent inhibitor of SARS coronavirus infection and spread. Virol J 2:69. https://doi.org/10.1186/1743-422X-2-69

16. National Health Commission (NHC) \& State Administration of Traditional Chinese Medicine (Trial Version 7). Diagnosis and treatment protocol for novel coronavirus pneumonia. https://busan china-consulate.org/chn/zt/4/P020200310548447287942.pdf. Accessed April 20, 2020

17. Liu J, Cao R, Xu M et al (2020) Hydroxychloroquine, a less toxic derivative of chloroquine, is effective in inhibiting SARS-CoV-2 infection in vitro. Cell Discov 6:1-4. https://doi.org/10.1038/ s41421-020-0156-0

18. Mehra MR, Desai SS, Ruschitzka F, Patel AN (2020) RETRACTED: Hydroxychloroquine or chloroquine with or without a macrolide for treatment of COVID-19: a multinational registry analysis. Lancet 22:S0140-6736(20)31180-6. https://doi. org/10.1016/S0140-6736(20)31180-6

19. Borba MGS , Almeida Val FF, Sampio VS (2020) Effect of high vs low doses of chloroquine diphosphate as adjunctive therapy for patients hospitalized with severe acute respiratory syndrome coronavirus 2 (SARS-CoV-2) infection: a randomized clinical trial. JAMA Netw Open 2020 3(4):e208857

20. Retallack H, Di Lullo E, Arias C et al (2016) Zika virus cell tropism in the developing human brain and inhibition by azithromycin. Proc Natl Acad Sci U S A 113(50):14408-14413 (Epub 2016 Nov 29)

21. Madrid PB, Panchal RG, Warren TK et al (2015) Evaluation of Ebola virus inhibitors for drug repurposing. ACS Infect Dis 1(7):317-326. https://doi.org/10.1021/acsinfecdis.5b00030(Epub 2015 May 11)

22. Arabi YM, Deeb AM, Al-Hameed F et al (2019) Saudi critical care trials group, macrolides in critically ill patients with middle east respiratory syndrome. Int J Infect Dis. 81:184-190. https:// doi.org/10.1016/j.ijid.2019.01.041(Epub 2019 Jan 25)

23. Hydroxychloroquine vs. Azithromycin for hospitalized patients with suspected or confirmed COVID-19, HAHPS (NCT04329832) Latest version (submitted April 7, 2020) on ClinicalTrials.gov, Accessed May 02, 2020 
24. Azithromycin for COVID-19 Treatment in Outpatients Nationwide, ACTION (NCT04332107) Latest version (submitted April 24, 2020) on ClinicalTrials.gov, Accessed May 02, 2020

25. Alhazzani W, Møller MH, Arabi YM et al (2020) Surviving sepsis campaign: guidelines on the management of critically Ill adults with coronavirus disease 2019 (COVID-19). Crit Care Med. https ://doi.org/10.1097/CCM.0000000000004363(Epub ahead of print)

26. Katzung BG, Masters SB, Trevor AJ (2011) Farmacologia generale e clinica. X Edizione Italiana a cura del Prof P. Preziosi. pag 931-961

27. Chu CM, Cheng VCC, Hung IFN (2004) Role of lopinavir/ritonavir in the treatment of SARS: initial virological and clinical findings. Thorax 59:252-256

28. Chan JF, Yao Y, Yeung ML, Deng W, Bao L, Jia L, Li F, Xiao C, Gao H, Yu P, Cai JP, Chu H, Zhou J, Chen H, Qin C, Yuen KY (2015) Treatment with lopinavir/ritonavir or interferon- $\beta 1 \mathrm{~b}$ Improves outcome of MERS-CoV infection in a nonhuman primate model of common marmoset. J Infect Dis 212(12):19041913. https://doi.org/10.1093/infdis/jiv392(Epub 2015 Jul 21)

29. Cao B, Wang Y, Wen D et al (2020) A trial of lopinavir-ritonavir in audults hospitalized with severe COVID-19. N Engl J Med. https://doi.org/10.1056/NEJMoa2001282(Epub ahead of print)

30. Arabi YM, Asiri AY, Assiri AM et al (2020) Treatment of Middle East respiratory syndrome with a combination of lopinavir/ritonavir and interferon- $\beta 1 \mathrm{~b}$ (MIRACLE trial): statistical analysis plan for a recursive two stage group sequential randomized controlled trial. Trials 21(1):8. https://doi.org/10.1186/s13063-019-3846-x

31. Bryan T. Alexander, Trevor Van Schoonevald, Erica Stohs et al. (2020) COVID-19 Antiviral and Pharmacotherapy Recommendations. Nebraska Medicine. https://www.nebraskamed.com/sites/ default/files/documents/covid-19/covid19-antiviral-pharmacoth erapy-recommendations

32. Yao T-T, Qian J-D, ZhuW Y, Wang-Y, Wang GQ (2020) A systematic review of lopinavir therapy for SARS coronavirus and MERS coronavirus-a possible reference for coronavirus disease-19 treatment option. J Med Virol 92(6):556-563. https:// doi.org/10.1002/jmv.25729

33. Lim J, Jeon S, Shin H-Y et al (2020) Case of the index patient who caused tertriary transmission of coronovirus disease 2019 in Korea: the application of lopinavir/ritonavir for the treatment of COVID-19 pneumonia monitored by quantitative RT-PCR. J Korean Med Sci 35(6):e79

34. Benn P, Ascar MR (2009) Role of darunavir in the management of HIV infection. HIV/AID (Auckl) 1:31-39

35. Valencia AG, Rodriguez MT, Magdaleno TF et al (2018) Darunavir/cobicistat showing similar effectiveness as darunavir/ ritonavir monotherapy despite lower trough concentrations. J Int AIDS Soc. https://doi.org/10.1002/jia2.25072

36. Santos JR, Curran A, Navarro-Mercade J et al (2019) Simplification of antiretroviral treatment from darunavir/ritonavir monotherapy to darunavir/cobicistat monotherapy: effectiveness and safety in routine clinical practice. AIDS Res Hum Retroviruses 35(6):513-518

37. Efficacy and safety of Darunavir and Cobicistat for Treatment of Pneumonia Caused by 2019-nCov (NCT04252274). Latest version (submitted January 29, 2020) on ClinicalTrials.gov. Accessed May 02, 2020

38. A randomised, open, controlled trial for darunavir/cobicistat or Lopinavir/ritonavir combined with thymosin a1 in the treatment of 2019-nCoV pneumonia. (ChiCTR2000029541) Latest version submitted Febrary 12, 2020 on https://www.chictr.org.cn(Chinese Clinical Trial Registry) Accessed May 02, 2020

39. Società Italiana di Malattie Infettive e Tropicali (SIMIT) (2020) Vademecum per la cura delle persone con malattia da COVID-19.
Edizione 2.0. Gruppo collaborativo - Terapia COVID-19 Lombardia

40. European Medicines Agency (EMA).Rezolsta https://www.ema. europa.eu/en/medicines/human/EPAR/rezolsta. Accessed 02, May 2020

41. Ribavirin EA (2020) Remdesivir, sofosbuvir, galidesivir, and tenofovir against SARS-CoV-2 RNA dependent RNA polymerase (RdRp): a molecular docking study. Life Sci. https://doi. org/10.1016/j.lfs.2020.117592(Epub ahead of print)

42. Mulangu S, Dodd LE, Davey LT et al (2019) A randomized, controlled trial of Ebola virus disease therapeutics. N Engl J Med 381:2293-2303. https://doi.org/10.1056/NEJMoal1910993

43. Agostini ML, Andres EL, Sims AC et al (2018) Coronavirus susceptibility to the antiviral remdesivir (GS-5734) is mediated by the viral polymerase and the proofreading exoribonuclease. $\mathrm{mBio}$ 9(2):e00221-e318. https://doi.org/10.1128/mBio.00221-18

44. Chan KW, Wong VT, Tang SCW (2020) COVID-19: an update on the epidemiological, clinical, preventive and therapeutic evidence and guidelines of integrative Chinese-western medicine for the management of 2019 novel coronavirus disease. Am J Chin Med. https://doi.org/10.1142/S01922415X20500378(Epub ahead of print)

45. Lu CC, Chen MY, Chang YL (2020) Potential therapeutic agents against COVID-19: what we know so far. J Chin Med Assoc. https://doi.org/10.1097/JCMA.0000000000000318(Epub ahead of print)

46. Holshue ML, DeBolt C (2020) First case of 2019 novel coronavirus in the United States. N Engl J Med 382:929-936

47. Scavone C, Brusco S, Bertini M et al (2020) Current pharmacologica treatments for COVID 19: wath's next. Br J Pharmacol. https://doi.org/10.1111/bph.15072(Epub ahead of print Review)

48. EMA provides recommendations on compassionate use of remdesivir for COVID-19. (EMA/152575/2020). Avialable on https ://www.ema.europa.eu/en/documents/product-information/rezol sta-epar-product-information.it.pdf. Accessed 02, May 2020

49. US Food and Drug Administration. Fact sheet for health care providers Emergency Use Authorization (EUA) of remdesivir (GS5734TM). https://www.fda.gov/media/137566/download. Accessed May 1, 2020a

50. Jordan PC, Stevens SK (2018) Nucleosides for the treatment of respiratory RNA virus infections. Antiviral Chem Chemother 26:1-19

51. Ruis C, Brown LK, Roy S et al (2018) Mutagenesis in norovirus in response to Favipiravir treatment. N Engl J Med 379(22):21732176. https://doi.org/10.1056/NEjMc1806941

52. Kerberg R, Lorenz E, Duraffour S et al (2019) Laboratory findings, compassionate use of Favipiravir, and outcome in patients with Ebola virus disease, guinea, 2015-a retrospective observational study. J Infect Dis 220(2):195-202. https://doi.org/10.1093/ infdis/jiz078

53. Principi N, Camilloni B, Alunno A et al (2019) Drugs for influenza treatment: is there significant news? Front Med (Lausanne) 6:109. https://doi.org/10.3389/fmed.2019.00109

54. Rocha-Pereira J, Jochmans D, Dallmeier K et al (2012) Favipiravir (T-705) inhibits in vitro norovirus replication. Biochem Biophys Res Commun 10(424):777-780. https://doi.org/10.1016/j. bbrc.2012.07.034(Epub 2012 Jul 15)

55. Dong L, Hu S, Gao J (2020) Discovering drugs to treat coronavirus disease 2019 (COVID-19). Drug Discov Thers 14(1):58-60. https://doi.org/10.5582/ddt.2020.0101

56. Liu C, Qiongqiong Z, Li Y et al (2020) Research and development on therapeutic agents and vaccines for COVID-19 and related human coronavirus diseases. ACS Cent Sci 6(3):315-331

57. Shiraki K, Daikoku T (2020) Favipiravir, an anti-influenza drug against life-threatening RNA virus infections. Pharmacol Ther. 
https://doi.org/10.1016/j.pharmthera.2020.107512(Epub ahead of print)

58. Morra ME, Van Thanh L, Kamel MG et al (2018) Clinical outcomes of current medical approaches for Middle East respiratory syndrome: a systematic review and meta-analysis. Rev Med Virol 28(3):e1977. https://doi.org/10.1002/rmv.1977

59. Cantong Z, Shaoyiong H, Fengping Z, Yong D (2020) Controversial treatment: an updated understanding of the coronavirus disease 2019. J Med Virol. https://doi.org/10.1002/jmv.25788

60. Wang D, Hu B, Hu C et al (2020) Clinical characteristics of 138 hospitalized patients with 2019 novel coronavirus-infected pneumonia in Wuhan China. JAMA. https://doi.org/10.1001/ jama.2020.1585(Epub ahead of print)

61. Russell CD, Millar JE, Baillie JK (2020) Clinical evidence does not support corticosteroid treatment for 2019-nCoV lung injury. Lancet. https://doi.org/10.1016/S0140-6736(20)30317-2(published online Feb 7)

62. Wu C, Chen X, Cai Y et al (2020) Risk factors associated with acute respiratory distress syndrome and death in patients with coronavirus disease 2019 pneumonia in Wuhan China. JAMA Intern Med. https://doi.org/10.1001/jamainternmed.2020.0994(Epub ahead of print)

63. Du B, Qiu HB, Zhan X et al (2020) Pharmacotherapeutics for the new coronavirus pneumonia. 43(3):173-176. Zhonghua Jie He He Hu Xi Za Zhi 43(3):173-176. https://doi.org/10.3760/cma .j.issn.1001-0939.2020.03.005

64. Xu X, Han M, Li T et al (2020) Effective treatment of severe COVID-19 patients with Tocilizumab. Accessed 19 Mar 2020

65. Mehta P, McAuley DF, Brown M et al (2020) COVID-19: consider cytokine storm syndromes and immunosuppression. Lancet. https://doi.org/10.1016/S0140-6736(20)30628-0(Epub ahead of print. PMID 32192578)

66. F. Hoffmann-La Roche Ltd. Roche initiates Phase III clinical trial of Actemra/RoActemra in hospitalized patients with severe COVID-19 pneumonia [press release]. Basel, Switzerland; Roche; March 19, 2020. https://www.roche.com/dam/jcr:f26cbbb1-999d42d8-bbea-34f2cf25f4b9/en/19032020-mr-actemra-covid-19-trial -en.pdf. Accessed 2020 Apr 2.

67. A Study to Evaluate the Safety and Efficacy of Tocilizumab in Patients With Severe COVID-19 Pneumonia (COVACTA) (NCT04320615). Latest version (submitted March 23, 2020) on ClinicalTrials.gov, Accessed May 02, 2020

68. Genentech, Inc, South San Francisco, CA. Actemra use in Coronavirus Disease 2019 (COVID-19) standard reply letter. (2020)

69. Sanofi and Regeneron begin global Kevzara ${ }^{\circledR}$ (sarilumab) clinical trial program in patients with severe COVID-19 [press release]. Cambridge, Mass and Tarrytown, NY; Sano-fi: 2020. https://www. news.sanofi.us/2020-03-16-Sanofi-and-Regeneron-begin-globa 1-Kevzara-R-sarilumab-clinical-trial-program-in-patients-withsevere-COVID-19. Accessed 2020 Mar 19.

70. Sobi to initiate a clinical study to evaluate whether anakinra and emapalumab may relieve complications associated with severe COVID-19 disease [press release]. Stock-holm, Sweden; Swedish Orphan Biovitrum AB (publ): 2020. https://www.sobi.com/sites/ default/files/pr/202003183346-1.pdf. Accessed 2020 Mar 30

71. Treatment of Acute Severe 2019-nCoV Pneumonia With Immunoglobulin From Cured Patients (NCT04264858) Latest version (submitted February 8, 2020) on ClinicalTrials.gov, Accessed May 02, 2020

72. Convalescent plasma for the treatment of severe and critical novel coronavirus pneumonia (COVID-19): a prospective randomized controlled trial (ChiCTR2000029757) Latest Version (submitted March 9, 2020). https://www.chictr.org.cn

73. Ronco C, Navalesi P, Vincent JL (2020) Coronavirus epidemic: preparing for extracorporeal organ support in intensive care. Lancet Respir Med 8(3):240-241. https://doi.org/10.1016/S2213 -2600(20)30060-6(Epub 2020 Feb 6)

74. Ronco C, Reis T, De Rosa S (2020) Coronavirus epidemic and extracorporeal Therapies in intensive care: si vis pace para bellum. Blood Purif. https://doi.org/10.1159/000507039(Epub ahead of print No abstract available)

75. Zuckier L, Moadel RM, Haramati LB, Freeman L (2020) Diagnostic evaluation of pulmonary embolism during the COVID-19 pandemic. J Nucl Med. https://doi.org/10.2967/jnumed.120.24557 1 (Online ahead of print)

76. Danzi GB, Loffi M, Galeazzi L, Gherbesi E (2020) Acute pulmonary embolism and COVID-19 pneumonia: a random association? Eur Heart J. https://doi.org/10.1093/eurheartj/ehaa254(Online ahead of print)

77. Chu KH, Tsang WK, Tang CS et al (2005) Acute renal impairment in coronavirus-associated severe acute respiratory syndrome. Kidney Int 67:698-705

78. Jung JY, Park BH, Hong SB et al (2011) Acute kidney injury in critically ill patients with pandemic influenza A pneumonia 2009 in Korea: a multicenter study. J Crit Care 26:577-585

79. Cheng Y, Luo R, Wang $\mathrm{K}$ et al (2020) Kidney disease is associated with in-hospital death of patients with COVID-19. Kidney Int 97:829-838

80. Mubarak M, Nasri H (2020) COVID-19 nephropathy; an emerging condition caused by novel coronavirus infection. J Nephropathol. https://doi.org/10.34172/jnp.2020.21

81. Hua S, Ming Y, Chen W, Li-Xia Y (2020) Renal histopathological analysis of 26 postmortem findings of patients with COVID-19 in China. Kidney Int 98(1):219-227. https://doi.org/10.1016/j. kint.2020.04.003

82. Larsen CP, Bourne TD, Wilson JD, et al (2020) Collapsing glomerulopathy in a patient with coronavirus disease 2019 (COVID19). Kidney Int Rep 5(6):935-939. https://doi.org/10.1016/j. ekir.2020.04.002

83. Kissling S, Rotman S, Gerber C et al (2020) Collapsing glomerulopathy in a COVID-19 patient. Kidney Int 98(1):228-231. https ://doi.org/10.1016/j.kint.2020.04.006

84. Riphagen S, Gomez X, Gonzalez-Martinez C et al (2020) Hyperinflammatory shock in children during COVID-19 pandemic. Lancet 395:1607

Publisher's Note Springer Nature remains neutral with regard to jurisdictional claims in published maps and institutional affiliations. 